\title{
Surface-area changes of glaciers in the Tibetan Plateau interior area since the 1970s using recent Landsat images and historical maps
}

\author{
WEI Junfeng, ${ }^{1,2}$ LIU Shiyin, ${ }^{1}$ GUO Wanqin, ${ }^{1}$ YAO Xiaojun, ${ }^{1,2,3} \mathrm{XU}$ Junli, ${ }^{1,2}$ \\ BAO Weijia, ${ }^{1,2}$ JIANG Zongli ${ }^{4}$ \\ ${ }^{1}$ State Key Laboratory of Cryospheric Sciences, Cold and Arid Regions Environmental and Engineering Research Institute \\ (CAREERI), Chinese Academy of Sciences, Lanzhou, China \\ E-mail: liusy@Izb.ac.cn \\ ${ }^{2}$ University of Chinese Academy of Sciences, Beijing, China \\ ${ }^{3}$ Geography and Environment College, Northwest Normal University, Lanzhou, China \\ ${ }^{4}$ Hunan Province Key Laboratory of Coal Resources Clean-Utilization and Mine Environment Protection, \\ Hunan University of Science and Technology, Xiangtan, China
}

\begin{abstract}
The Tibetan Plateau interior area (TPIA), often termed the Qangtang Plateau, is distinguished by many dome-like mountains higher than $6000 \mathrm{ma.s.l}$. These mountains provide favourable conditions for the development of ice caps and glaciers of extreme continental/subpolar type. According to historical topographic maps (1959-80) and recent Landsat images (2004-11), continuous retreat was observed and the glacierized part of this area decreased by $9.5 \%\left(0.27 \% \mathrm{a}^{-1}\right)$ with respect to the total glacier area of $8036.4 \mathrm{~km}^{2}$ in the $1970 \mathrm{~s}$. Glaciers in the Zhari Namco basin have experienced the highest area shrinkage, with a reduction rate of $0.72 \% \mathrm{a}^{-1}$, while the smallest reduction occurred in Bangong Co $\left(0.12 \% \mathrm{a}^{-1}\right)$ and Dogai Coying basins $\left(0.11 \% \mathrm{a}^{-1}\right)$. A regional gradient of area loss was found, with a larger decrease in the south and a smaller decrease in the north of the plateau. Comparisons indicate glaciers have experienced smaller shrinkage in the TPIA than in surrounding regions. Glacier shrinkage in the TPIA is mainly attributed to an increase in air temperature, while precipitation, glacier size and positive difference of glaciation also played an important role.
\end{abstract}

KEYWORDS: glacier mapping, remote sensing

\section{INTRODUCTION}

As the dominant factor responsible for sea-level rise, global glacier shrinkage in recent decades has attracted the attention of glaciologists worldwide (Ren and others, 2011; Gardner and others, 2013). The Tibetan Plateau (TP), described as the 'Third Pole' and Asia's 'water tower', develops the largest cryosphere outside the polar region and has experienced accelerating warming during recent decades (Xiao and others, 2007; Kang and others, 2010). Many investigations of glaciers reveal that retreat was common but differed in the various regions/basins (Xiao and others, 2007; Ren and others, 2011). Moreover, monitored glaciers in the TP have experienced accelerating reduction during the past two decades (Cogley, 2011; Bolch and others, 2012; Yao and others, 2012), which might trigger level increases for closed lakes and dramatically impact on the livelihoods and activities of people in downstream regions by having an active influence on water resources and geohazards (Shi and others, 2008; Immerzeel and others, 2010; Zhang and others, 2011; Lei and others, 2012; Yao and others, 2012). However, glaciers in the western TP have demonstrated a mass gain in the past decade (Gardelle and others, 2012; Jacob and others, 2012; Kääb and others, 2012; Wang and others, 2012; Yao and others, 2012; Gardner and others, 2013) that poses a need for continuous glacier monitoring on a large spatial scale.

The Tibetan Plateau interior area (TPIA), in the northcentral TP, is encircled by the Kunlun mountains to the north, the Karakoram mountains to the west and the
Nyainqentanglha range to the southeast. The inaccessibility of the region due to its remoteness and high altitude have led to its being less investigated and short of in situ measurements on glaciers. The remote-sensing technique provides an alternative and valid means of access to generate information on glacier dynamics in the region. In this study, Landsat Thematic Mapper (TM)/Enhanced TM Plus (ETM+) scenes and Chinese topographic maps (CTMs) were utilized to show the recent changes of glaciers in the TPIA, and their impact is analyzed at the end of the paper.

\section{STUDY AREA}

The TPIA, often termed the Qangtang Plateau, is located between the west-central part of the Kunlun mountains to the north and the Gangdise range to the south, and covers parts of the Karakoram mountains, the Tanghla and Nyainqentanglha ranges (Fig. 1). In this region, various closed drainage basins are developed with the distribution of many dome-like mountains higher than 6000 ma.s.l. These mountains provide favourable conditions for the development of ice caps (e.g. Caixiong Kangri and Zangser Kangri). China's largest ice field, Purog Kangri glacier, and largest ice cap, Chongce glacier, both occur in this region. Glaciers in the TPIA are all of the extreme continental/ subpolar type, with ice frozen to the bedrock (Shi and others, 2008), and meltwater from these glaciers feeds hundreds of lakes of various sizes (Zhang and others, 2011). The climate in the TPIA, though dominated by the 


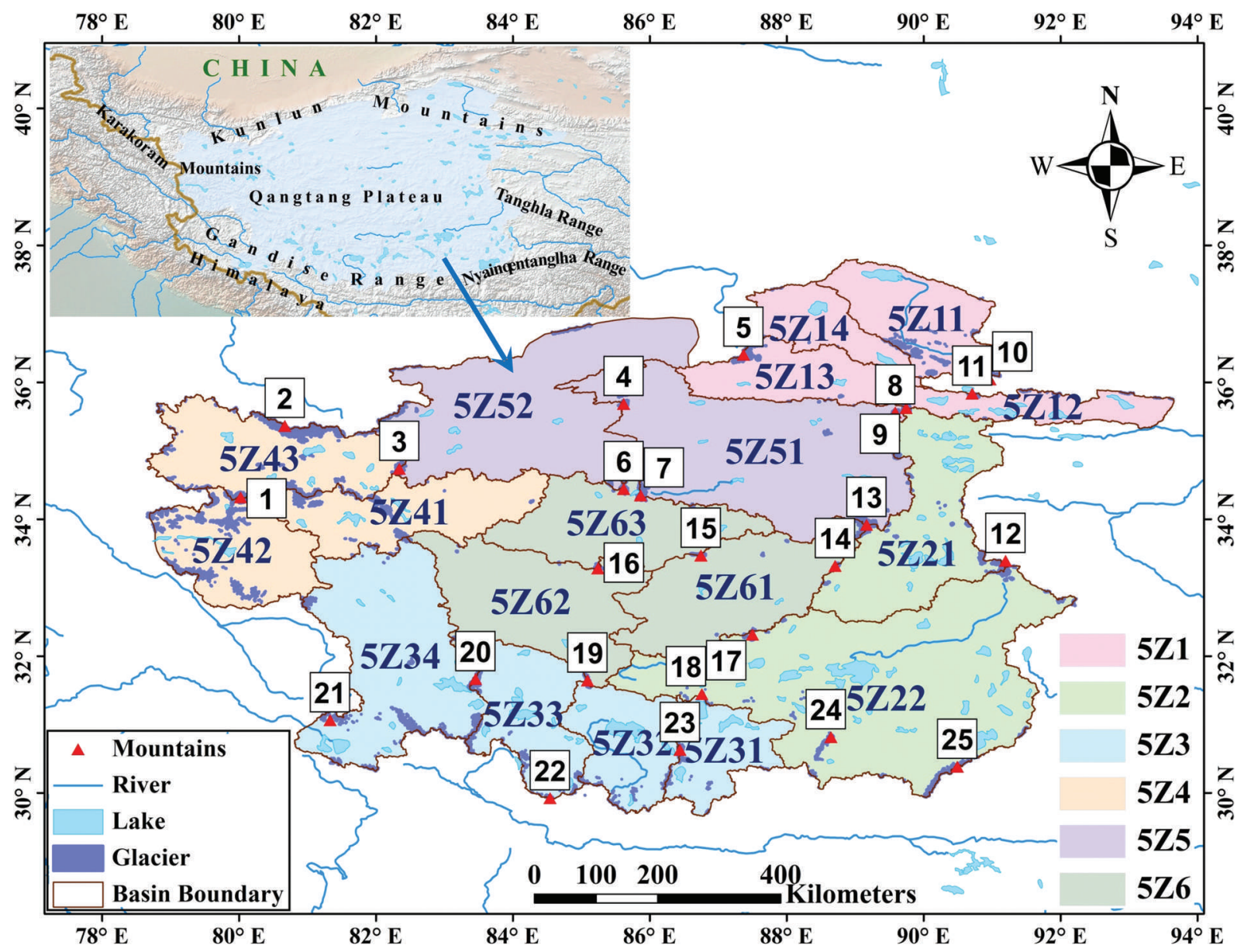

Fig. 1. Sketch of the study area. The mountains are (1) Caixiong Kangri; (2) Kunlun peak; (3) Tuze Kangri; (4) Songzhiling; (5) Muz Tag peak; (6) Burog Kangri; (7) Zangser Kangri; (8) Kangzhag Ri; (9) Jinyang Kangri; (10) Buka Daban peak; (11) Malan ice cap; (12) Geladaindong peak; (13) Puruog Kangri; (14) Xiyaergang; (15) Mayi Kangri; (16) Duguer; (17) Mugagebo; (18) Qingpagonglong; (19) Xiakangjian; (20) Longger; (21) Kangrinboqe peak; (22) Loinbo Kangri; (23) Bobogawu; (24) Shenzhajiegang; (25) Nyainqentanglha peak.

Indian monsoon in summer and the westerly in other seasons, is cold and dry (Yao and others, 2012; Joswiak and others, 2013). The annual mean air temperature in most parts of the region is $<0^{\circ} \mathrm{C}$, with the mean warmest month (July) near-surface temperature $<14^{\circ} \mathrm{C}$, and varies with the altitude of the terrain. The northern part containing the west Kunlun mountains and Karakoram mountains has the lowest annual mean air temperature $\left(-2.13^{\circ} \mathrm{C}\right)$, and the eastern part containing the Tanghla range has the highest $\left(0.17^{\circ} \mathrm{C}\right)$. The annual precipitation is $50-400 \mathrm{~mm}$, and has increased most in winter, with a stronger increase in the north than in the south of the TPIA, and the strongest increase in the west Kunlun mountains (Zhao and others, 2004; Wang and others, 2008). Following the coding system of river basins applied in the World Glacier Inventory (http://nsidc.org/data/docs/noaa/g01130_glacier_ inventory/), the study area is subdivided into six secondlevel sub-basins: Ayakkum lake and Hoh Xil lake basin (5Z1), Siling Co basin (5Z2), Zhari Namco basin (5Z3), Bangong Co basin (5Z4), Dogai Coying basin (5Z5) and Yibug Cako basin (5Z6), and further into 18 third-level sub-basins (Fig. 1). In addition, we divide the TPIA into seven sub-regions according to their local climate settings: the Gangdise range (GR), Karakoram mountains (KaM), Kunlun mountains (KM), Nyainqentanglha range (NR), Qangtang Plateau (QP), Tanghla range (TR) and Himalaya (HI) (Fig. 1).

\section{GLACIER MAPPING USING SATELLITE DATA}

The present glacier outlines were generated from Landsat scenes acquired by TM/ETM+ (Table 1 ). These multispectral and multitemporal scenes, with spatial resolution of $30 \mathrm{~m}$, are available from the US Geological Survey (USGS, https:// Ipdaac.usgs.gov/get_data/). All Landsat scenes were orthorectified with the Shuttle Radar Topography Mission (SRTM) and ground control points from the Global Land Survey 2005 (GLS2005) dataset (USGS, 2011). The accuracy of these Landsat scenes is controlled by their horizontal shift of less than one pixel to each other or non-differential GPS data (Bolch and others, 2010a; Guo and others, 2013). Glaciers were then segmented by a ratio threshold method which is a division of the visible or near-infrared band and shortwave infrared band (Paul, 2002). Ice patches larger than $0.01 \mathrm{~km}^{2}$ were mapped. This method is not good at discriminating seasonal snowpatches, clouds and ice surface with debris cover from bare ice of glaciers, so manual improvement was applied where necessary, by referencing image scenes without snow or cloud-free image scenes that were acquired at nearly the same time (Fig. 2). Only four glaciers with debris cover on the terminus area are found in the study area, and their boundaries were delineated manually.

The final contiguous ice coverage was divided into individual glacier polygons using topographical ridgelines (TRLs), which were automatically generated based on SRTM version 4 (available from http://srtm.csi.cgiar.org/) (Guo and 
Table 1. Major datasets used in this study

\begin{tabular}{|c|c|c|c|c|}
\hline Source & Year & Quantity & Utilization & $\begin{array}{c}\text { Specified } \\
\text { year* }\end{array}$ \\
\hline \multirow{4}{*}{$\begin{array}{l}1: 50000 \\
\text { topographic map }\end{array}$} & 1959 & 1 & \multirow{12}{*}{$\begin{array}{l}\text { Glacier identification } \\
\text { for historical state, with } \\
\text { relevant original aerial } \\
\text { photographs as add- } \\
\text { itional information }\end{array}$} & \multirow{12}{*}{$\sim 1970$} \\
\hline & 1968 & 16 & & \\
\hline & 1974 & 7 & & \\
\hline & 1980 & 34 & & \\
\hline \multirow{8}{*}{$\begin{array}{l}1: 100000 \\
\text { topographic map }\end{array}$} & 1968 & 5 & & \\
\hline & 1969 & 6 & & \\
\hline & 1970 & 85 & & \\
\hline & 1971 & 63 & & \\
\hline & 1972 & 6 & & \\
\hline & 1973 & 1 & & \\
\hline & 1974 & 11 & & \\
\hline & 1978 & 1 & & \\
\hline \multirow[t]{7}{*}{ Landsat 5 TM } & 2004 & 1 & \multirow{11}{*}{$\begin{array}{l}\text { Glacier identification } \\
\text { for recent state, remov- } \\
\text { ing influence of sea- } \\
\text { sonal snow and cloud } \\
\text { by combining images } \\
\text { covering the same place } \\
\text { in nearby years }\end{array}$} & \multirow[t]{11}{*}{$\sim 2009$} \\
\hline & 2005 & 1 & & \\
\hline & 2006 & 6 & & \\
\hline & 2007 & 17 & & \\
\hline & 2009 & 27 & & \\
\hline & 2010 & 20 & & \\
\hline & 2011 & 3 & & \\
\hline \multirow[t]{4}{*}{ Landsat 7 ETM+ } & 2004 & 2 & & \\
\hline & 2005 & 1 & & \\
\hline & 2007 & 2 & & \\
\hline & 2010 & 2 & & \\
\hline
\end{tabular}

* Specified years, just for annual rate of glacier recession, were defined as $\mathrm{SY}=\frac{1}{\mathrm{IC}} \sum_{1}^{n} \mathrm{ic} \cdot \mathrm{AY}$, where IC is the entire glacier area of the TPIA, $n$ is the total count of scenes used in our study, ic is the glacier area generated from the particular scene and AY is the year of the particular scene acquired.

others, 2011). We assume that these SRTM-based TRLs did not change with time within the period considered in the study. TRLs were not well generated, and were later manually revised, over large flat-topped glaciers due to the coarse resolution of SRTM on the glaciers. SRTM was also utilized to extract geometrical parameters of a glacier-like maximum, minimum, median elevations, aspects and slopes, etc., as well as hypsometry, using a method suggested by Paul and others (2009) and Frey and Paul (2012). Parameters derived in this way for glaciers in 2009 may be slightly biased from the actual values due to surface movements and changes in ice thickness and extent.

\section{CREATING OUTLINES OF GLACIERS IN THE 1970s}

Glaciers in the TPIA in the 1970s were inventoried (the first Chinese Glacier Inventory, termed first CGI) based on CTMs with scales of $1: 50000$ and $1: 100000$. Various glacier parameters were manually measured on paper maps; for example, glacier area was measured using a planimeter (Jiao and Zhang, 1988a,b,c; Yang and others, 1988; Zhang and Jiao, 1988; Shi and others, 2009). The above-mentioned dataset cannot be directly applied to derive glacier changes compared with glacier outlines derived from satellite images as described earlier (Frauenfelder and Kääb, 2009; Bolch and others, 2010a). The outlines of the first CGI were then digitized manually based on scanned and well-georeferenced CTMs at scales of $1: 50000$ and $1: 100000$, and validated with reference to the original aerial photographs on which the CTMs were based (Fig. 2). The spatial resolution of scanned CTMs is $4 \mathrm{~m}$ for maps at a scale of $1: 50000$ and $9 \mathrm{~m}$ for those at 1:100000. They were first georeferenced following the original map coordinate of the 1954 Beijing

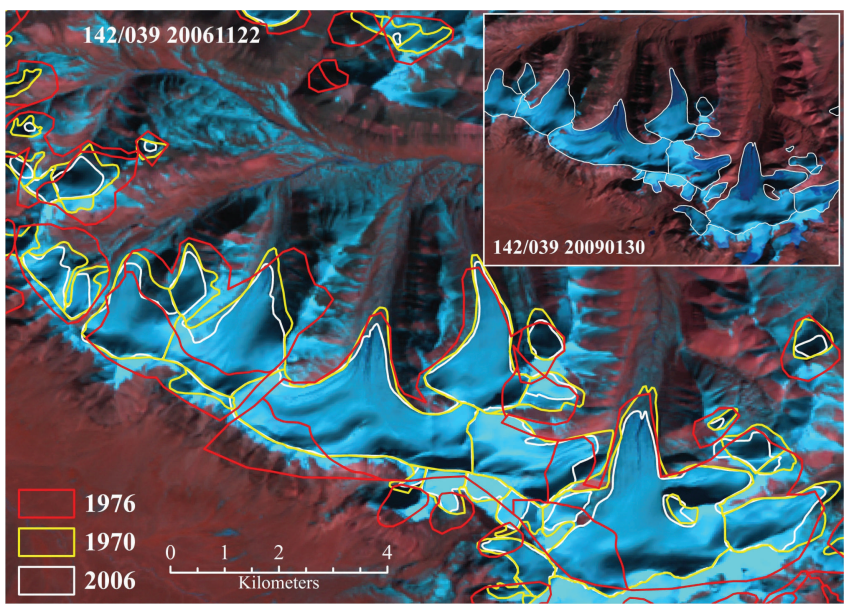

Fig. 2. Glacier outline mapping. The yellow and white outlines are the results of this study, extracted from CTMs and Landsat separately; the red outline is from the Randolph Glacier Inventory v3.2 (Arendt and others, 2012). The backgrounds are Landsat images.

Geodetic Coordinate System (BJ54) geoid (datum level is Yellow Sea mean sea level at Qingdao Tidal Observatory in 1956) and then reprojected into World Geodetic System 1984 (WGS84)/Earth Gravity Model 1996 (EGM96) utilizing 77 national trigonometric reference points of China over the TPIA. The same method for dividing individual glaciers and the geometric parameters of the satellite-image-based inventory is applied for the digitized first CGI from SRTM. For a retreating glacier, terminus elevation in the 1970 s read from SRTM may be slightly lower than values derived based on the digital elevation models (DEMs) from the equivalent period, due to the melting of ice mass in the DEM grids at the terminus area before 2000, while that for glaciers in 2009 from SRTM may be slightly higher than the real terminus elevation because of thinning at the terminus area since 2000. Therefore terminus elevations, in both the 1970s and 2009, of a glacier read from SRTM may have implications for the thickness change, at least before 2000 .

\section{ERROR ANALYSIS}

The uncertainty of glacier outlines arises from positional and processing errors associated with glacier delineation (RaCoviteanu and others, 2008; Bolch and others, 2010a). No distinct horizontal shift was observed in Landsat TM/ETM+ scenes (Bolch and others, 2010a; Guo and others, 2013). After eliminating the impact of seasonal snow, cloud and debris cover manually, an accuracy of less than half a pixel was achieved. Consequently, the error of glacier area generated from Landsat scenes, $E_{\mathrm{L}}$, can be defined as (Bolch and others, 2010b; Guo and others, 2013)

$$
E_{\mathrm{L}}=n \cdot \lambda_{\mathrm{L}}^{2} / 2
$$

where $n$ is the total count of pixels along the outline of ice coverage except for pixels along TRLs, and $\lambda_{\mathrm{L}}$ is the resolution of Landsat scenes. The nominal accuracies of CTMs at scales of $1: 50000$ and $1: 100000$ are 0.5 and $0.75 \mathrm{~mm}$ on slopes of $<6^{\circ}$ and $\geq 6^{\circ}$ (GB/T 12343.1-2008; SAC, 2008). When the digital CTMs (DCTMs) are coregistered to the Landsat scenes, the errors are $12.8 \mathrm{~m}$ for DCTMs at scales of $1: 50000$ and $19.4 \mathrm{~m}$ for $1: 100000$. Uncertainty related to the digitization of glacier outlines 
Table 2. Glacier state and changes in drainage basins during 1970s-2009

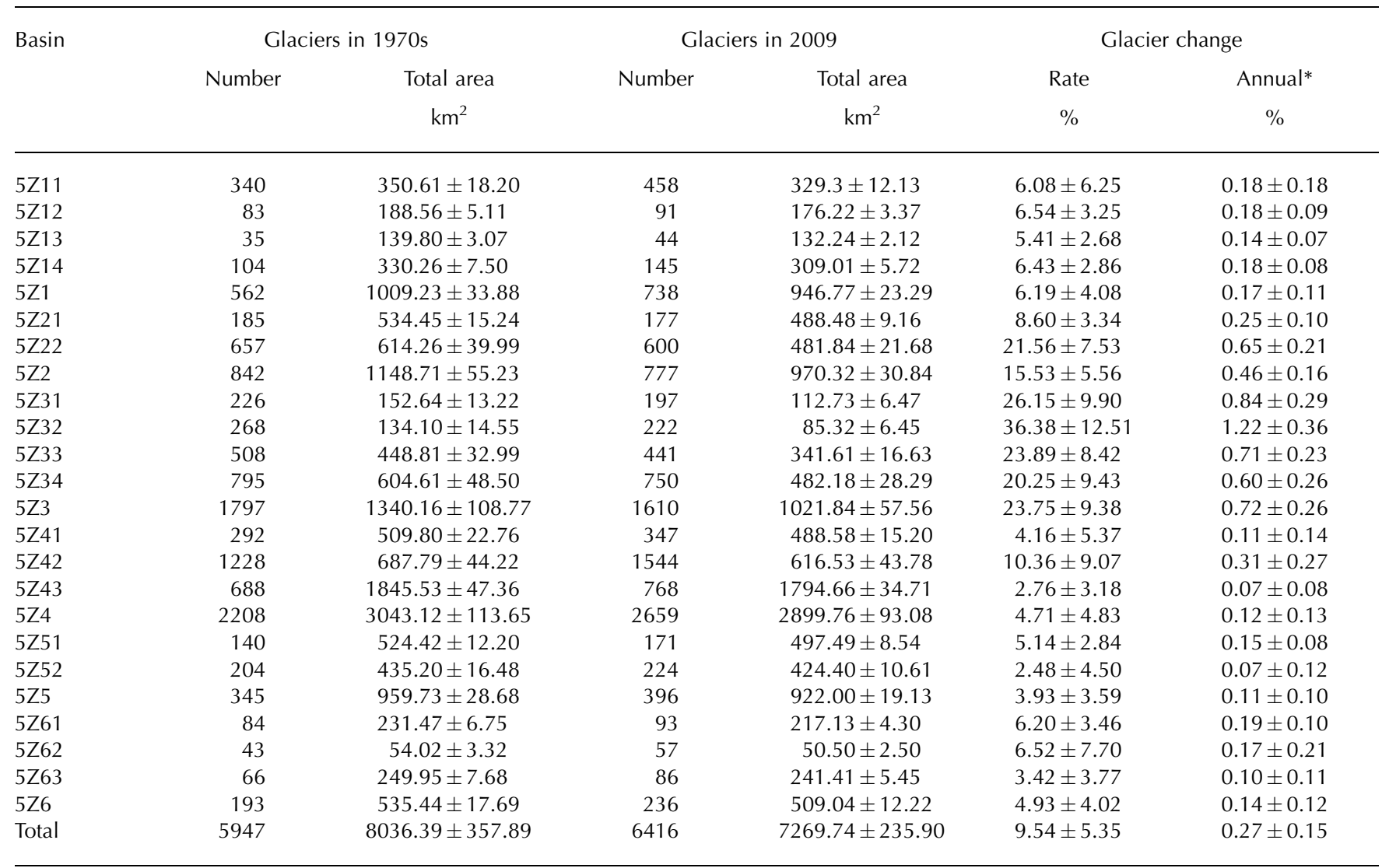

*The periods were calculated by the specified years in corresponding drainage basins.

from the DCTMs may be within three pixels, meaning that the errors $\left(\lambda_{\mathrm{T}}\right)$ for glacier outlines may be 12 and $27 \mathrm{~m}$ for DCTMs at scales of $1: 50000$ and $1: 100000$ respectively. Accordingly, the error of glacier area, $E_{\mathrm{T}}$, measured from DCTMs is the integration of uncertainty along the perimeter of a glacier polygon from DCTMs at various scales (Ye and others, 2003; Shangguan and others, 2009) and can be calculated by

$$
E_{\mathrm{T}}=n \cdot \lambda_{\mathrm{T}} \cdot \sqrt{\left(\lambda_{\mathrm{T}} / 2\right)^{2}+\lambda_{\mathrm{M}}^{2}}
$$

where $\lambda_{\mathrm{T}}$ is the interpretation resolution of the DCTM, and $\lambda_{M}$ is the co-registration error. The error for changes in a glacier area $E_{\mathrm{C}}$ can be obtained by

$$
E_{\mathrm{C}}=\sqrt{\left(E_{\mathrm{L}}\right)^{2}+\left(E_{\mathrm{T}}\right)^{2}}
$$

Our results indicate that the uncertainty for glacier area from DCTMs in the $1970 \mathrm{~s}$ is of the order of $4.5 \%$, while it is $3.2 \%$ for Landsat images in 2009. The low uncertainty $(\leq 5 \%)$ of both inventories indicates that they are of sufficient quality to be applied to the detection of glacier area changes in this region (Paul, 2002; Bolch and others, 2010a). The errors of glacier area and their areal change in a basin were therefore evaluated (Table 2). The results shows that higher error occurs in basins with smaller glacier area since the method for uncertainty assessment is pixel-based along the glacier outlines.

\section{GLACIER DISTRIBUTION}

According to the present study (Table 2; Fig. 3), there are 6416 glaciers in the whole TPIA in 2009, with a total area of
$7269.7 \mathrm{~km}^{2}$, whereas there were 5947 glaciers, with a total area of $8036.4 \mathrm{~km}^{2}$, in the $1970 \mathrm{~s}$. The digitized first CGI differs slightly from the published first CGI dataset, in that 606 glaciers and $200.3 \mathrm{~km}^{2}$ glacier area are added, which by mistake were not inventoried or measured at that time. There are also differences in other geometrical parameters because of the difference in measurement techniques and DEMs used. Here we demonstrate the general distribution characteristics of glaciers based on the 2009 inventory of glaciers in the TPIA. As the results show, large glaciers dominate the total glacier area in the region: for example, 22 glaciers each $>32 \mathrm{~km}^{2}$ in area contribute about one-fifth of the total glacier area in the TPIA, while the smallest glaciers $\left(\leq 0.5 \mathrm{~km}^{2}\right)$ comprise $70 \%$ of the total number but only $9.4 \%$ of the total area (Fig. $6 \mathrm{a}$, further below). Almost $15.7 \%$ of the glacier area is centralized in the altitude range 5900$6000 \mathrm{~m}$ (Fig. 4). The surface slopes of most glaciers are $22-30^{\circ}$ on average, while glaciers with slopes of $12-17^{\circ}$ cover $58.6 \%$ of the total area (Fig. 5a, left panel). In general, large glaciers have gentle surface slopes (Fig. 5a, right panel) and tend to be south- and southeast-facing, but most glaciers have a north or northeast aspect (Fig. 5b).

Glaciers are unevenly distributed in different parts of the study area (Table 2; Fig. 3). 5 Z4 in the northwest of the TPIA is one of the most glacierized basins, with ice coverage of $2899.76 \mathrm{~km}^{2}(39.9 \%$ of the total TPIA). In this sub-basin the ice coverage rate reaches $2.9 \%$. $5 Z 6$ in the interior is the least glacierized basin, with a glacier area contribution of $7.0 \%$ and an ice coverage rate of $0.4 \%$. More than one-third of glacier area occurs in the Kunlun mountains, while only $0.8 \%$ is situated in the Himalaya. The largest mean glacier sizes occur in $5 Z 5$ in the north-central part of the study area 

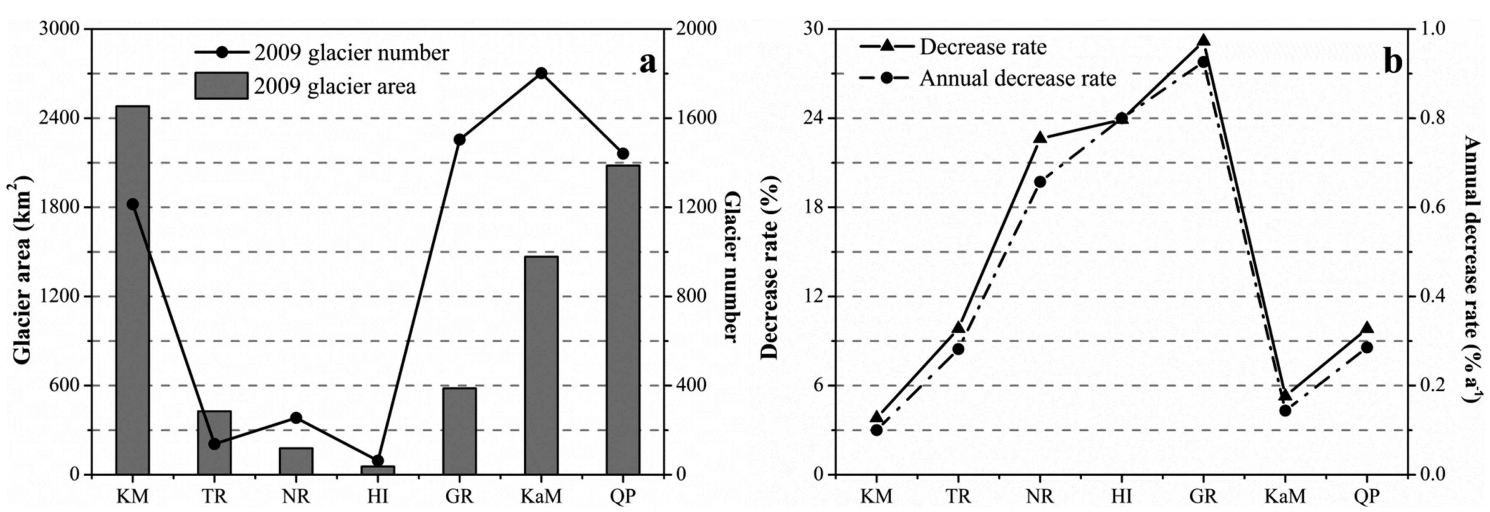

Fig. 3. Glacier state and changes in sub-regions during 1970s-2009.

and the Tanghla range in the east, while the smallest sizes occur in $5 Z 3$ and the Gangdise range in the southwest. $5 Z 1$ and $5 Z 2$, located in the northeast and southeast respectively, have similar glacier distributions in terms of mean glacier sizes and contributions to total area.

Glaciers exhibit spatial characteristics regarding the distribution of average maximum $\left(H_{\max }\right)$, median $\left(H_{\text {med }}\right)$ and minimum $\left(H_{\min }\right)$ elevations in individual basins and different mountain regions (Fig. 4). Glaciers in the TPIA range from 5722 to 6021 ma.s.l., with an $H_{\text {med }}$ of 5881 ma.s.l. Glaciers in $5 Z 1$ (Kunlun mountains) have the lowest $H_{\max }$ $H_{\text {med }}$ and $H_{\text {min, }}$ while the highest values are in $5 Z 3$ (Gangdise range). This pattern may be related to the longitudinal gradients of climate considering the average elevations of the Kunlun and Gangdise mountains. It is important to note that the values of $H_{\text {med }}$ and $H_{\text {min }}$ exceed 5800 and $5600 \mathrm{~m}$ respectively, in all basins except $5 Z 1$. The altitude range of glacier occurrence varies from $274 \mathrm{~m}$ in $5 Z 4$ up to $422 \mathrm{~m}$ in 5Z5, whereas the greatest is situated in the Tanghla range and varies from $289 \mathrm{~m}$ down to $230 \mathrm{~m}$ in the Gangdise range. The elevation difference between the highest altitude and the snowline altitude (SLA) (here we refer to $H_{\text {med }}$ as SLA) of a glacier (i.e. $H_{\text {max }}-H_{\text {med }}$ ) is defined as the positive difference of glaciation (PDG, a similar indicator to accumulation-area ratio (AAR)), which may demonstrate the capacity of accumulation on a glacier and the potential for glacier development in a mountainous region (Wang, 1992). As indicated by Wang (1992), an exponential relationship exists between the glacier coverage in a basin or on a mountain and their average PDG: a larger PDG always corresponds to high glaciation (greater coverage). The PDG is only $140 \mathrm{~m}$ on average for the whole TPIA, so the region does not show favourable conditions for glacier development compared with other mountain regions.

\section{GLACIER CHANGES}

Comparing earlier and recent glacier extents, we found that glaciers in the TPIA were generally in retreat, while $<1.5 \%$ of glaciers advanced. In the period 1970s-2009, the total glacier area decreased by $766.65 \mathrm{~km}^{2}$, or $9.5 \%$ of the total glacier area in the $1970 \mathrm{~s}\left(0.27 \% \mathrm{a}^{-1}\right)$. Figure 6 shows the changes in number and area of glaciers of various size classes. Glaciers in different regions retreated at different speeds (Table 2; Fig. 3). The most drastic shrinkage occurred in $5 Z 3$, which has lost over one-fifth of its ice coverage, at a rate of $0.72 \% \mathrm{a}^{-1}$. Glaciers in $5 Z 2$ have experienced a moderate recession in area by $15.5 \%\left(0.46 \% \mathrm{a}^{-1}\right)$, and those in $5 Z 1$ and $5 Z 4-6$ had an area reduction of $<10 \%$ at rates of $0.12-0.17 \% \mathrm{a}^{-1}$. As for glacier shrinkage in the different

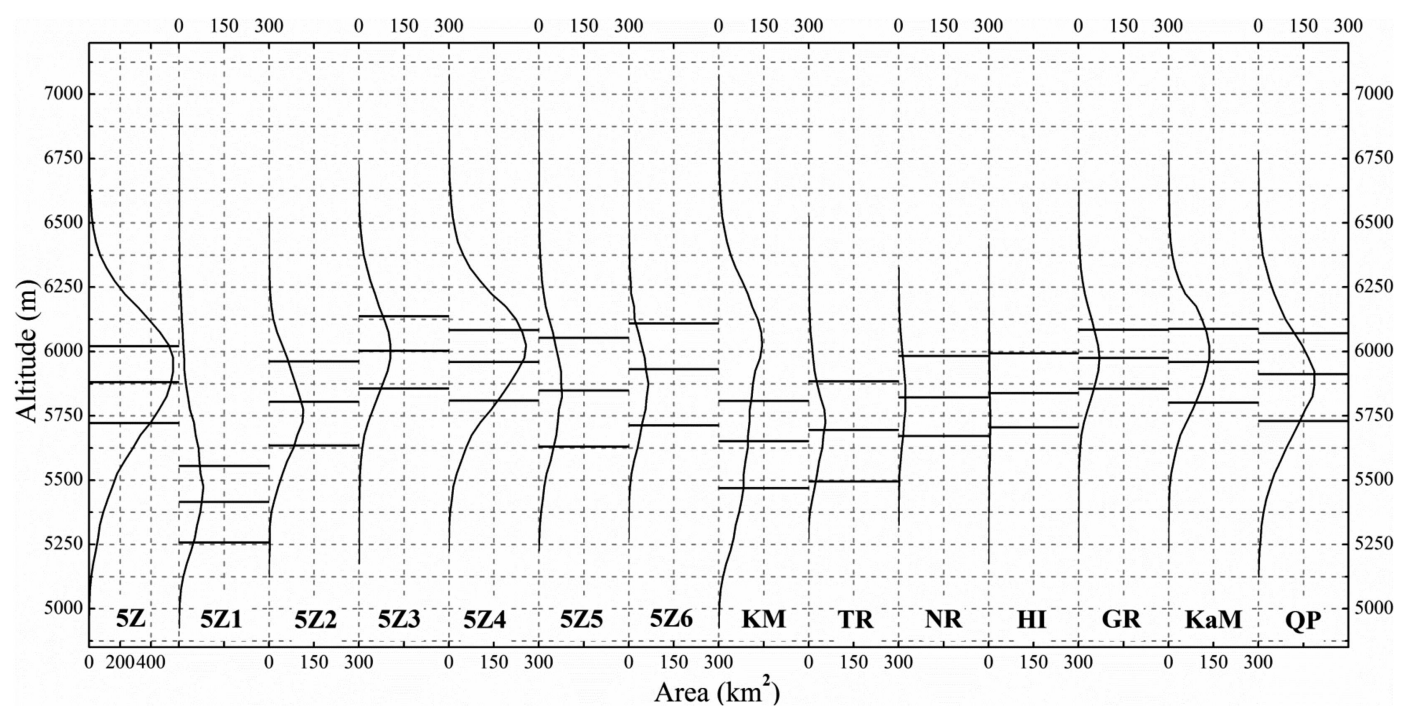

Fig. 4. Hypsography of glaciers in drainage basins and sub-regions. The three black lines in each panel depict values of $H_{\max }$ (up), $H_{\text {med }}$ (middle) and $H_{\min }($ down), respectively. 

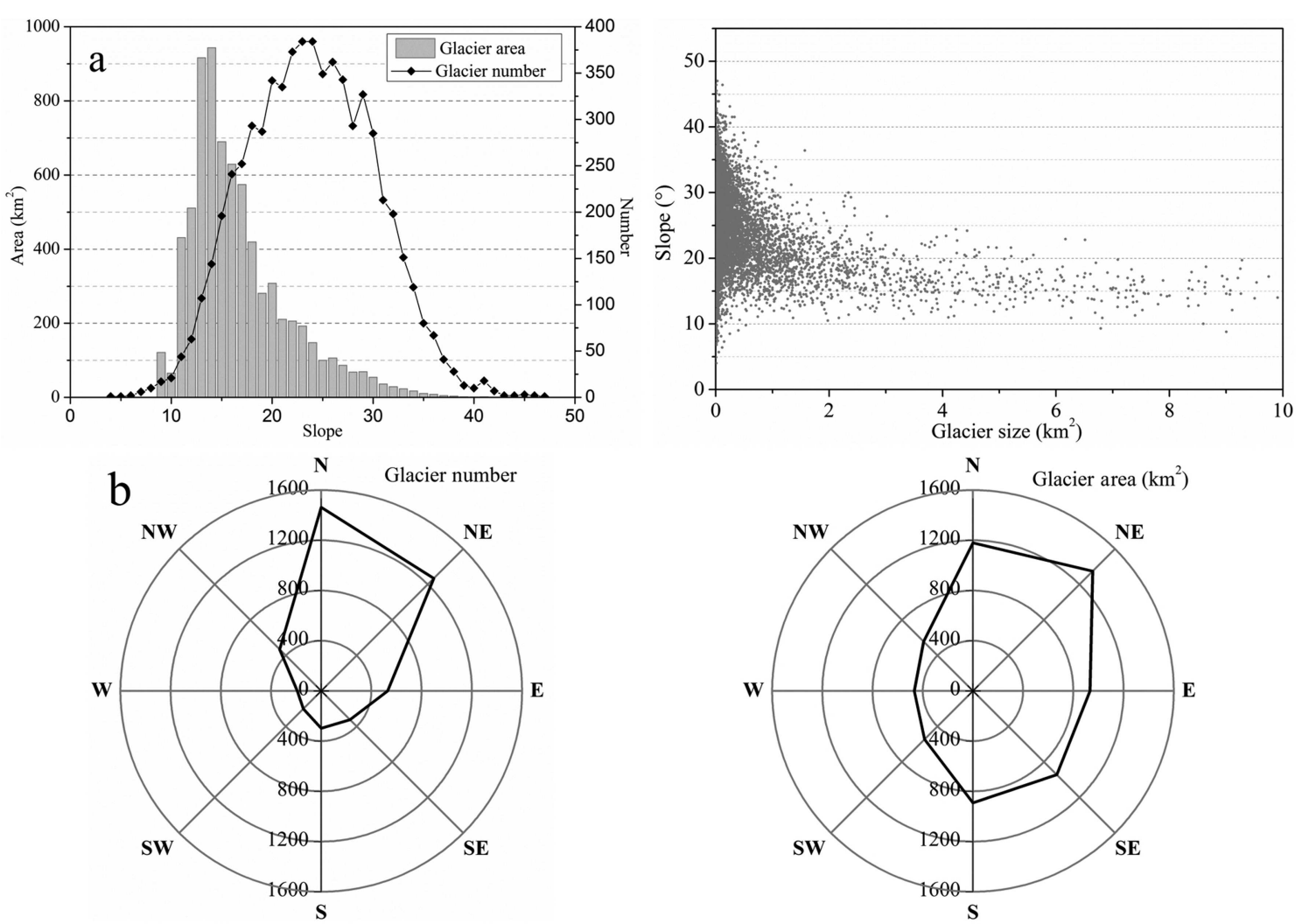

Fig. 5. Characteristics of glacier slope and aspect. (a) Mean slope of glacier number/area (left panel); each bar represents a slope interval of $1^{\circ}$ and area $\leq 10 \mathrm{~km}^{2}$ (right panel). (b) Mean aspect of glacier number (left panel) and area (right panel); each sector represents an aspect interval of $45^{\circ}$.

mountain ranges, a large area reduction by $>20 \%$ is found in Gangdise, Nyainqentanglha and the western Himalaya, with a rate of loss of $>0.66 \% \mathrm{a}^{-1}$. Glaciers in Qangtang Plateau and the Tanghla range experienced only about half of that rate $\left(0.28 \% \mathrm{a}^{-1}\right)$, while the Karakoram and west Kunlun mountains have seen the least area shrinkage, by $0.14 \% \mathrm{a}^{-1}$ and $0.10 \% \mathrm{a}^{-1}$ respectively.

Glacier numbers have also changed, as a result of either the disappearance of very small glaciers or the disintegration of large glaciers. The total number of glaciers $<0.5 \mathrm{~km}^{2}$ in area has increased by $13.8 \%$ since the $1970 \mathrm{~s}$. This is linked to a decrease in the number of glaciers $0.5-2.0 \mathrm{~km}^{2}$ in area, by $4.9 \%$ of their total in the 1970s. The number of disappeared glaciers accounts for only $0.7 \%$ of the total number in the 1970s. A total of 607 glaciers, covering an area of $82.28 \mathrm{~km}^{2}$, have disappeared, nearly $97 \%$ of which were in the smallest size class. The highest incidence of disappearance occurred in $5 Z 3(18.4 \%$ of the glacier number, covering $3.6 \%$ of the total glacier area in the basin) and the Gangdise range (20.4\% and $5.0 \%$ respectively). Only $3.8 \%$ of glaciers in the Kunlun mountains disappeared, covering $0.1 \%$ of the glacierized area in this region. There are 13 glaciers with nearly unchanged area, all $<0.7 \mathrm{~km}^{2}$, three of which are located in the Kunlun mountains and the others in the Karakoram mountains. We also found 92 glaciers that increased in size in the period 1970s-2009, of which 57 were situated in the Karakoram mountains and none in the Himalaya. The extreme advancing glacier is
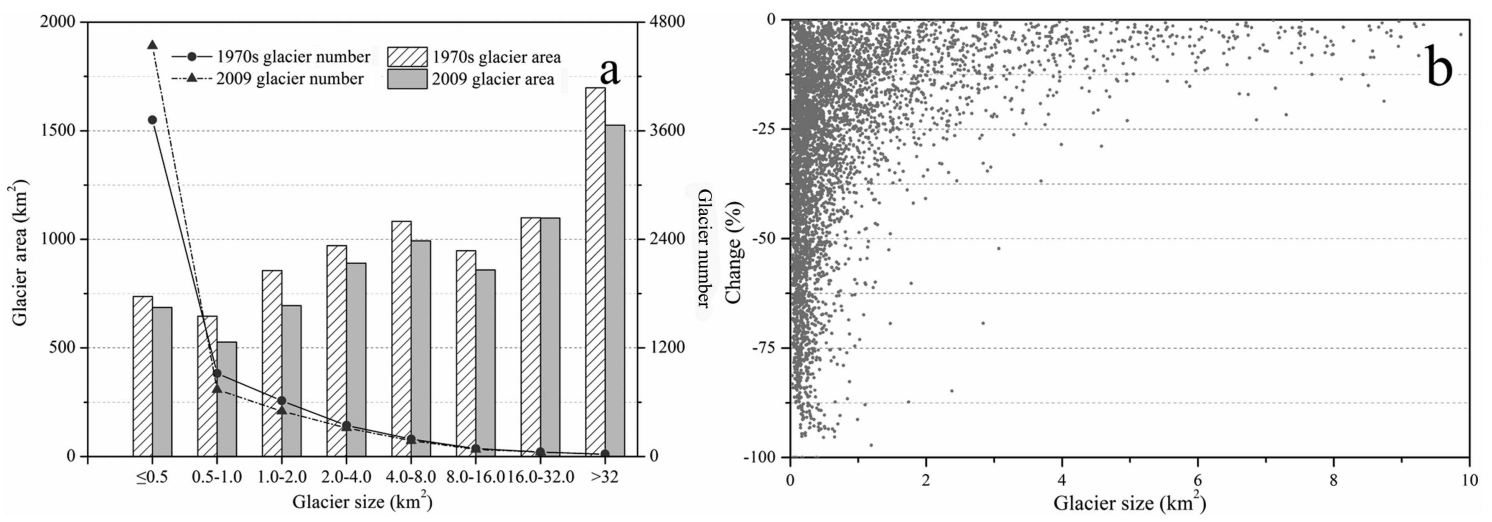

Fig. 6. Glacier characteristics according to area-size classes. (a) Glacier numbers and areas in 1970s and 2009; (b) relative area changes for glaciers with area $\leq 10 \mathrm{~km}^{2}$. 


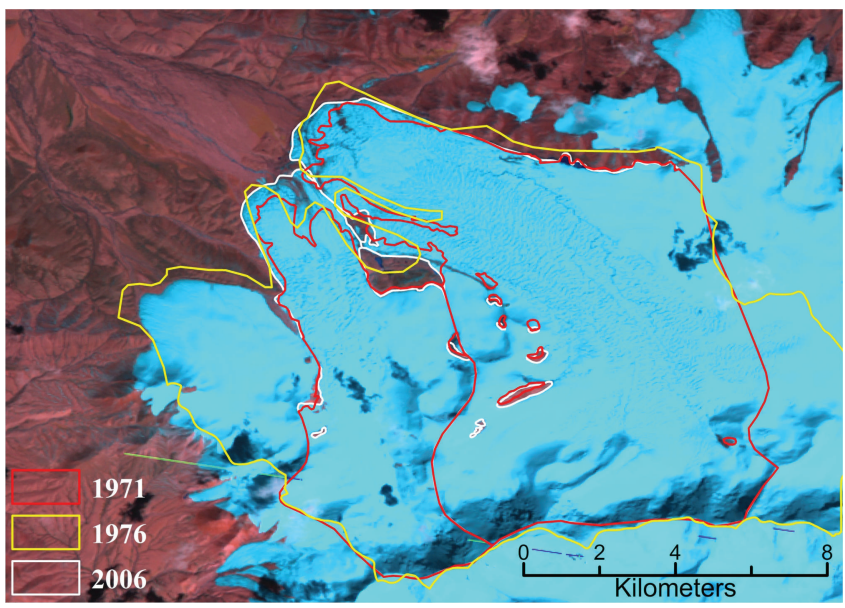

Fig. 7. Advancing glaciers occurring in Kunlun mountains. The yellow and white outlines are the results of this study, extracted from CTMs and Landsat separately; the red outline is from the Randolph Glacier Inventory v3.2 (Arendt and others, 2012).

located in the Kunlun mountains, with a total area increase of $2.40 \mathrm{~km}^{2}$ (Fig. 7).

Glacier retreat is also demonstrated by an uplift in glacier terminus elevations. The average $H_{\min }$ for the whole TPIA has risen by $33 \mathrm{~m}$. The rise is more pronounced in $5 Z 1-3$ and $5 Z 6(50-60 \mathrm{~m}$ on average) than in $5 Z 5(<10 \mathrm{~m})$ (Table 3$)$. The sharpest rise was found for glaciers in the Nyainqentanglha range, while the rise in the Kunlun mountains was relatively small. Uncertainties exist for terminus elevations determined by the same SRTM DEM; for example, the estimated rise in terminus elevation may be less than the actual rise, but the change in PDG may also be an indicative signature of glacier retreat in the region. An increase in $H_{\text {med }}$ or decrease in PDG has been identified for glaciers in all basins and various mountains in the region; the average decrease in PDG is $24 \mathrm{~m}$ for the whole study area, with the largest decrease, of $42 \mathrm{~m}$, in $5 \mathrm{Z} 1$.

\section{DISCUSSION}

The climate on the TPIA is characterized by the Indian monsoon in summer and the westerly in winter (Yao and others, 2012; Joswiak and others, 2013). The accumulation on glaciers in the southern TPIA is supplied by continental summer precipitation, while glaciers in the north experience a winter accumulation period (Bolch and others, 2010a). Previous studies indicate that annual mean air temperature and annual precipitation have increased over the TPIA, though with regional and seasonal differences (Yao and others, 1995; Wu and others, 2007). The warming is more obvious in the northern TPIA than in the south, and significant warming occurred in the cold season, with obvious winter warming in the southern TPIA. In the period 1955-2004 the annual mean air temperature varies from east $\left(-2.13^{\circ} \mathrm{C}\right)$ to center $\left(-0.6^{\circ} \mathrm{C}\right)$ to west $\left(0.17^{\circ} \mathrm{C}\right)$, but the annual mean air temperatures have increased by a similar amplitude $\left(1.4^{\circ} \mathrm{C}\right)$. The strongest increase in annual precipitation has taken place in the northwestern TPIA, and annual precipitation has increased more in the north than in the south, while the precipitation increase was lowest in winter (Zhao and others, 2004; Shangguan and others, 2007; Wang and others, 2008).
Table 3. Changes in $H_{\min }$ of drainage basins and sub-regions

\begin{tabular}{lccc}
\hline Drainage basin & $\begin{array}{c}\text { Change } \\
\mathrm{m}\end{array}$ & Sub-region & $\begin{array}{c}\text { Change } \\
\end{array}$ \\
\hline $5 Z 1$ & 57 & KM & \\
$5 Z 2$ & 50 & TR & 6 \\
$5 Z 3$ & 58 & NR & 27 \\
$5 Z 4$ & 32 & HI & 76 \\
$5 Z 5$ & 9 & GR & 29 \\
$5 Z 6$ & 53 & KaM & 51 \\
$5 Z$ & 33 & QP & 40 \\
& & & 44 \\
\hline
\end{tabular}

Glacier distribution and changes during the last $\sim 40$ years are characterized by clear regional differences (Table 2; Fig. 3). This may be related to the different topography and climatic settings of the various areas, as well as climate change. The northwestern and southwestern TPIA (e.g. Karakoram, western Kunlun and Gangdise) are relatively humid and thus highly glacierized. Large glaciers and glaciers with large PDG are found in the western and interior TPIA. As the approximation of SLA, $H_{\text {med }}$ increases from east to west and is in agreement with the distribution of equilibrium-line altitude mainly influenced by the Indian monsoon and westerly (Yao and others, 2012). As mentioned in the previous section, the trend of regional glacier changes in the TPIA is not similar to changes in annual mean air temperature but seasonal mean air temperature. The general slight retreat of glaciers or expansion of some glaciers in the Kunlun and Karakoram mountains was a combined effect of extreme air temperature increase coinciding with the most pronounced precipitation increase. Such a complex pattern of changes in both temperature and precipitation might give rise to a weakly negative or even slightly positive mass balance during 1999/2003-08 (Gardelle and others, 2012; Kääb and others, 2012), hence a slowdown in glacier retreat in the region during the recent decade as well as a general weak glacier retreat during the 1970s-2009 (Tables 2 and 4). The glacierized area in the TPIA is dominated by glaciers $\leq 1.0 \mathrm{~km}^{2}$ in area, which comprise $82.2 \%$ of the total number, and $91.8 \%$ in the Gangdise range, a much higher contribution than in the surrounding regions (Shangguan and others, 2006; Bolch and others, 2010b). These small glaciers have shown a sensitive response to climate change

Table 4. Glacier reduction in the TP and surrounding regions

\begin{tabular}{|c|c|c|c|c|}
\hline \multirow[t]{3}{*}{ Location } & \multirow[t]{3}{*}{ Period } & \multicolumn{2}{|c|}{ Area change } & \multirow[t]{3}{*}{ Source } \\
\hline & & Rate & Annual & \\
\hline & & $\%$ & $\%$ & \\
\hline Geladandong & 1969-2000 & 1.7 & 0.06 & Lu and others (2002) \\
\hline Tarim river basin & 1963-99 & 17.3 & 0.53 & Liu and others (2006) \\
\hline Tien Shan & 1960-2000 & 11.5 & 0.30 & $\begin{array}{l}\text { S. Wang and others } \\
\qquad(2011)\end{array}$ \\
\hline East Pamirs & 1966-99 & 7.9 & 0.25 & $\begin{array}{l}\text { Shangguan and others } \\
(2006)\end{array}$ \\
\hline Southeastern Tibet & 1980-2001 & 19.9 & 0.90 & Yao and others (2012) \\
\hline Qangtang Plateau & 1970-2000 & 4.3 & 0.15 & $\begin{array}{l}\text { L. Wang and others } \\
\qquad(2011)\end{array}$ \\
\hline TPIA & 1970s-2009 & 9.5 & 0.27 & This paper \\
\hline
\end{tabular}




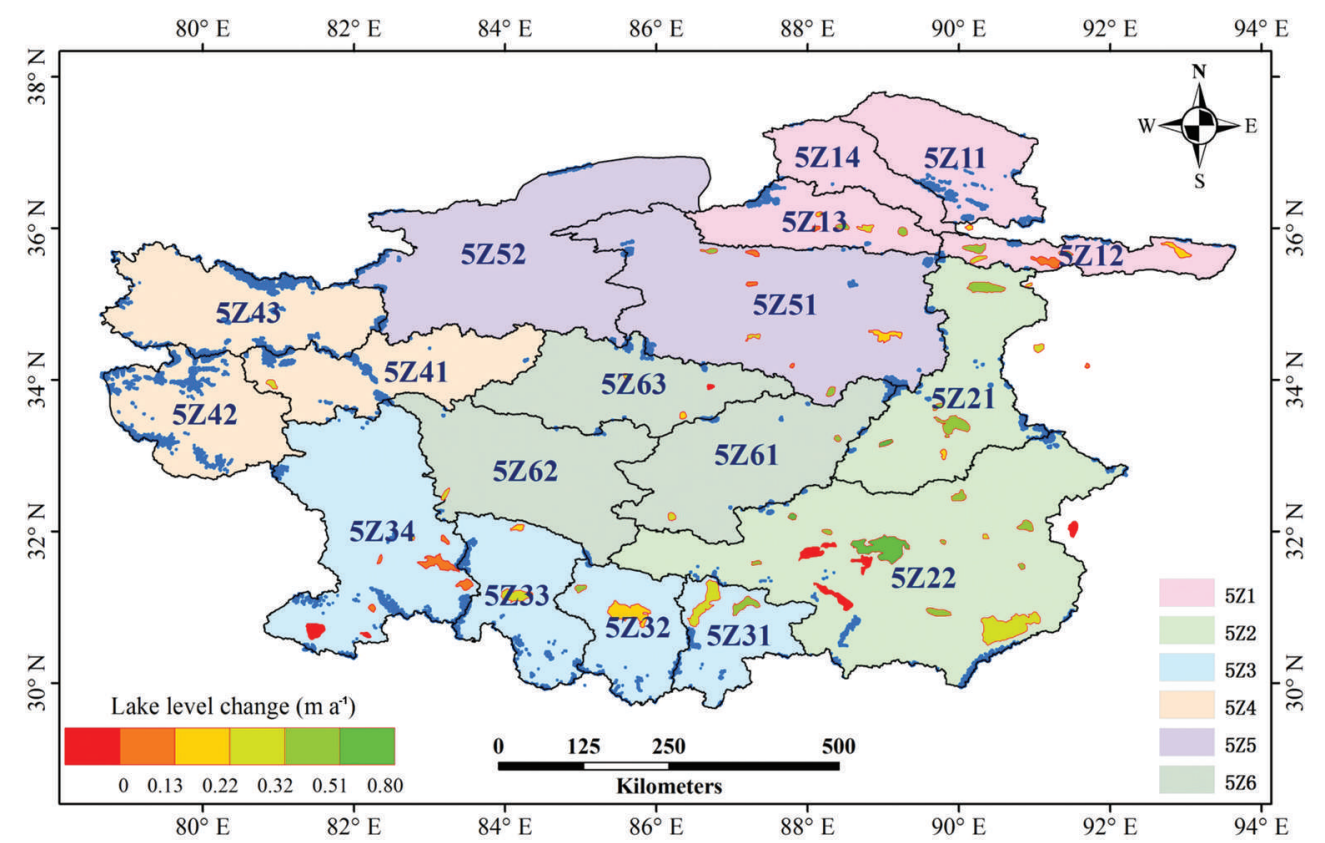

Fig. 8. Lake level change rates in the period 2003-09 (based on Zhang and others, 2011), with glaciers in blue.

(Haeberli and Hoelzle, 1995; Ye and others, 2003), with a much higher percentage area reduction and some small glaciers even disappearing (Fig. 6) (e.g. in the Gangdise range and $5 Z 3$ basin). Glaciers with large PDGs in the interior of the TPIA and Tanghla range retreated only slightly, perhaps because of their wide firn basin, high AAR, etc. (Wang, 1992). In summary, under extremely cold climatic conditions in the TPIA, changes in moisture may be a key factor controlling the development of glaciers and their response to climate change, although changes in the seasonality of air temperature are always fundamental (Oerlemans and Fortuin, 1992; Liu and others, 1999). In addition, regional differences in glacier change may be related to topographical configurations (e.g. PDGs) that determine the accumulation rate in the firn basin.

Ding and others (2006) divided glacier recession into three groups with annual decrease rates of $\leq 0.1 \% \mathrm{a}^{-1}, 0.1-$ $0.2 \% \mathrm{a}^{-1}$ and $>0.2 \% \mathrm{a}^{-1}$. The glacier recession was then promoted from the second level (moderate reduction) to the third level (most intense shrinkage) for the whole TPIA, and was also detected in some detailed regions. L. Wang and others (2011) showed that glaciers in the TPIA decreased by $0.12 \% \mathrm{a}^{-1}$ and $0.20 \% \mathrm{a}^{-1}$ in the periods $1970-90$ and 1990-2000 respectively, and in total have retreated at a rate of $0.15 \% \mathrm{a}^{-1}$ during $1970-2000$. Combined with a glacier recession rate of $0.27 \% \mathrm{a}^{-1}$ during the $1970 \mathrm{~s}-2009$, this indicates that glaciers have experienced a continuous and accelerating recession for the whole TPIA. Based on our study, glaciers in the Nyainqentanglha range in the Nam Co drainage basin have decreased by $24.2 \%\left(0.70 \% \mathrm{a}^{-1}\right)$ in the period 1970s-2009, which is a slightly lower rate than during 1977-2010 (0.81\% $\mathrm{a}^{-1}$; Wang and others, 2012) but much higher than during 1976-2001 $\left(0.27 \% \mathrm{a}^{-1}\right.$; Bolch and others, 2010a). On the south slope of the western Kunlun mountains, glacier area decreased by $0.06 \% \mathrm{a}^{-1}$ in the period 1970-91 and increased by $0.06 \% \mathrm{a}^{-1}$ during $1991-$ 2000, while the annual recession rate increased from $0.02 \% \mathrm{a}^{-1}$ during $1970-2001$ to $0.03 \% \mathrm{a}^{-1}$ in the $1970 \mathrm{~s}-$ 2009 (Shangguan and others, 2007). Although the recession has accelerated markedly, glacier constriction in the whole
TPIA is still slight compared to the surrounding regions (Table 4), showing that glaciers in the central TP are less responsive to climate change (L. Wang and others, 2011; Yao and others, 2012).

Glaciers in the TPIA are an important water resource for animals, grasslands and wetlands in the region (Shi and others, 2008). Meltwater from glaciers is also the key source controlling the changes of lakes in the TPIA (Zhang and others, 2011; Lei and others, 2012). A recent study shows that $>80 \%$ of lakes in the TPIA have experienced a lake level rise of $0.14 \mathrm{~m} \mathrm{a}^{-1}$ on average during 2003-09, and only a few lakes showed a slight lake level decrease by 0.02-0.04 $\mathrm{m} \mathrm{a}^{-1}$ (Fig. 8). The most prominent lake level rise has been seen in Cedo Caka lake, by a rate as high as $0.80 \mathrm{~m} \mathrm{a}^{-1}$ (Zhang and others, 2011). Lake level rise has been evident for lakes in the southern TPIA, where glaciers have experienced intensive shrinkage. The observation data from meteorological stations in this region imply that precipitation increased less than evaporation (Zhang and others, 2011), and of the closed lakes glacier-fed lakes have a different response to climate change than non-glacier-fed lakes in the same climate region (Lei and others, 2012). Therefore the meltwater generated from accelerating glacier/ snow recession could be the primary reason for lake level increase. The lake level increases provide further indirect evidence for accelerating glacier recession (Lei and others, 2012). Furthermore, the continuous and accelerating reduction of glaciers has an active influence on regional water storage and geohazards in downstream regions, by causing flooding and devastating wetlands and grasslands (Yao and others, 2007; Zhang and others, 2011).

\section{CONCLUSION}

Based on multi-source datasets, determination of glacier changes was achieved but with varied results. We detected the recent state of glaciers and their changes over the past few decades. The results imply that the first CGI in the 1970s, after being rechecked using CTMs and other sources, is still an alternative dataset for monitoring glacier changes. Our 
study demonstrates that glaciers in the TPIA are in a period of continuous and accelerating recession, at an annual rate of $0.27 \% \mathrm{a}^{-1}$ during the $1970 \mathrm{~s}-2009$. As a result of integrating the influence of climate pattern and glacier characteristics, the intensity of glacier recession differed significantly from region to region, as more pronounced glacier shrinkage has occurred in the southern TPIA while glaciers in the northwest have experienced the smallest recession. Moreover, the accelerating recession of glaciers is considered an important factor for lake level increases in the TPIA.

\section{ACKNOWLEDGEMENTS}

This work was supported by the National Natural Science Foundation of China (grant No. 41190084), the Ministry of Science and Technology of China (MOST) (grant No. 2013FY111400), the Chinese Academy of Sciences (CAS) under grant XDA05090302, and the State Key Laboratory of Cryospheric Sciences, CAREERI, CAS (grant No. SKLCS2012-09). The data applied in the study were a result of an immediate past project from MOST (grant No. 2006FY110200). Satellite images are from USGS and NASA.

\section{REFERENCES}

Arendt A and 77 others (2012) Randolph Glacier Inventory (RGI), Vers. 1.0: a dataset of Global Glacier Outlines. Global Land Ice Measurements from Space, Boulder, CO. Digital media: http:// www.glims.org/RGl/randolph.html

Bolch T, Menounos B and Wheate R (2010a) Landsat-based inventory of glaciers in western Canada, 1985-2005. Remote Sens. Environ., 114(1), 127-137 (doi: 10.1016/j.rse.2009.08.015)

Bolch T and 7 others (2010b) A glacier inventory for the western Nyainqentanglha range and Nam Co Basin, Tibet, and glacier changes 1976-2009. Cryosphere, 4(2), 429-467 (doi: 10.5194/ tc-4-419-2010)

Bolch Tand 11 others (2012) The state and fate of Himalayan glaciers. Science, 336(6079), 310-314 (doi: 10.1126/science.1215828)

Cogley JG (2011) Present and future states of Himalaya and Karakoram glaciers. Ann. Glaciol., 52(59), 69-73 (doi: 10.3189/ 172756411799096277)

Ding Y, Liu S, Li J and Shangguan D (2006) The retreat of glaciers in response to recent climate warming in western China. Ann. Glaciol., 43, 97-105 (doi: 10.3189/172756406781812005)

Frauenfelder R and Kääb A (2009) Glacier mapping from multitemporal optical remote sensing data within the Brahmaputra river basin. In Malingreau J-P ed. Proceedings of the 33rd International Symposium on Remote Sensing of Environment, 4-8 May 2009, Stresa, Italy. (Paper 299) International Center of Remote Sensing of Environment, Tucson, AZ. CD-ROM

Frey $\mathrm{H}$ and Paul $\mathrm{F}$ (2012) On the suitability of the SRTM DEM and ASTER GDEM for the compilation of topographic parameters in glacier inventories. Int. J. Appl. Earth Obs. Geoinform., 18, 480490 (doi: 10.1016/j.jag.2011.09.020)

Gardelle J, Berthier E and Arnaud Y (2012) Slight mass gain of Karakoram glaciers in the early 21 st century. Nature Geosci., 5(5), 322-325 (doi: 10.1038/ngeo1450)

Gardner AS and 15 others (2013) A reconciled estimate of glacier contributions to sea level rise: 2003 to 2009. Science, 340(6134), 852-857 (doi: 10.1126/science.1234532)

Guo W, Liu S, Yu P and Xu J-L (2011) Automatic extraction of ridgelines using on drainage boundaries and aspect difference. Sci. Surv. Mapp., 36(6), 210-212 (doi: CNKI:SUN:CHKD.0. 2011-06-075) [in Chinese with English summary]

Guo W, Liu S, Wei J and Bao W (2013) The 2008/09 surge of central Yulinchuan glacier, northern Tibetan Plateau, as monitored by remote sensing. Ann. Glaciol., 54(63 Pt 2), 299-310 (doi: 10.3189/2013AoG63A495)
Haeberli W and Hoelzle M (1995) Application of inventory data for estimating characteristics of and regional climate-change effects on mountain glaciers: a pilot study with the European Alps. Ann. Glaciol., 21, 206-212

Immerzeel WW, Van Beeke LPH and Bierkens MFP (2010) Climate change will affect the Asian water towers. Science, 328(5984), 1382-1385 (doi: 10.1126/science.1183188)

Jacob T, Wahr J, Pfeffer WT and Swenson S (2012) Recent contributions of glaciers and ice caps to sea level rise. Nature, 482(7386), 514-518 (doi: 10.1038/nature10847)

Jiao K and Zhang Z eds (1988a) Glacier inventory of China VII. Qinghai-Xizang Plateau interior area (drainage basins of Siling Lake). Science Press. Academia Sinica, Lanzhou Institute of Glaciology and Geocryology, Beijing [in Chinese]

Jiao K and Zhang Z eds (1988b) Glacier inventory of China VII. Qinghai-Xizang Plateau interior area (drainage basins of the Dogaicoring and Yibuchaka Lakes). Science Press. Academia Sinica, Lanzhou Institute of Glaciology and Geocryology, Beijing [in Chinese]

Jiao K and Zhang Z eds (1988c) Glacier inventory of China VII. Qinghai-Xizang Plateau interior area (drainage basins of Zharinam Lake). Science Press. Academia Sinica, Lanzhou Institute of Glaciology and Geocryology, Beijing [in Chinese]

Joswiak DR, Yao T, Wu G, Tian L and Xu B (2013) Ice-core evidence of westerly and monsoon moisture contributions in the central Tibetan Plateau. J. Glaciol., 59(213), 56-66 (doi: 10.3189/ 2013JoG12J035)

Kääb A, Berthier E, Nuth C, Gardelle J and Arnaud Y (2012) Contrasting patterns of early twenty-first-century glacier mass change in the Himalayas. Nature, 488(7412), 495-498 (doi: 10.1038/nature11324)

Kang S, Xu Y, You Q, Flügel W-A, Pepin N and Yao T (2010) Review of climate and cryospheric change in the Tibetan Plateau. Environ. Res. Lett., 5(1), 015101 (doi: 10.1088/1748-9326/5/1/)

Lei $Y$ and 6 others (2012) Glacier mass loss induced the rapid growth of Linggo Co on the central Tibetan Plateau. J. Glaciol., 58(207), 177-184 (doi: 10.3189/2012JoG11J025)

Liu S, Wang N, Ding Y and Xie Z (1999) On the characteristics of glacier fluctuations during the last 30 years in the Ürümqi river basin and the estimation of temperature rise in the high mountain area. Adv. Earth Sci., 14(3), 279-285 [in Chinese with English summary]

Liu S and 7 others (2006) Impact of the glacial change on water resources in the Tarim river basin. Acta Geogr. Sin., 61(5), 482-490 [in Chinese]

Lu A, Yao T, Liu S, Ding L and Li G (2002) Glacier change in the Geladandong area of the Tibetan Plateau monitored by remote sensing. J. Glaciol. Geocryol., 24(5), 559-562 [in Chinese with English summary]

Oerlemans J and Fortuin JPF (1992) Sensitivity of glaciers and small ice caps to greenhouse warming. Science, 258(5079), 115-117

Paul F (2002) Changes in glacier area in Tyrol, Austria, between 1969 and 1992 derived from Landsat Thematic Mapper and Austrian glacier inventory data. Int. J. Remote Sens., 23(4), 787-799 (doi: 10.1080/01431160110070708)

Paul F and 9 others (2009) Recommendations for the compilaton of glacier inventory data from digital sources. Ann. Glaciol., 50(53), 119-126 (doi: 10.3189/172756410790595778)

Racoviteanu AE, Arnaud Y, Williams MW and Ordoñez J (2008) Decadal changes in glacier parameters in the Cordillera Blanca, Peru, derived from remote sensing. J. Glaciol., 54(186), 499-510

Ren J, Ye B, Ding Y and Liu S (2011) Initial estimate of the contribution of cryospheric change in China to sea level rise. Chinese Sci. Bull., 56(16), 1661-1664 (doi: 10.1007/s11434011-4474-3)

Shangguan D and 9 others (2006) Monitoring the glacier changes in the Muztag Ata and Konggur mountains, east Pamirs, based on Chinese Glacier Inventory and recent satellite imagery. Ann. Glaciol., 43, 79-85 (doi: 10.3189/172756406781812393) 
Shangguan D and 8 others (2007) Glacier changes in the west Kunlun Shan from 1970 to 2001 derived from Landsat TM/ETM+ and Chinese glacier inventory data. Ann. Glaciol., 46, 204-208 (doi: 10.3189/172756407782871693)

Shangguan D, Liu S, Ding Y, Ding L, Xu J and Li J (2009) Glacier changes during the last forty years in the Tarim Interior River basin, northwest China. Progr. Natur. Sci., 19(6), 727-732 (doi: 10.1016/j.pnsc.2008.11.002)

Shi Y, Liu S, Ye B, Liu C and Wang Z eds. (2008) Concise glacier inventory of China. Shanghai Popular Science Press, Shanghai

Shi Y, Liu C and Kang E (2009) The glacier inventory of China. Ann. Glaciol., 50(53), 1-4 (doi: 10.3189/172756410790595831)

Standardization Administration of People's Republic of China (SAC) (2008) GB/T 12343.1-2008. Compilation specifications for national fundamental scale maps - Part 1: compilation specifications for 1:25000/1:50000/1:100000 topographic maps. General Administration of Quality Supervision, Inspection and Quarantine, Beijing [in Chinese]

US Geological Survey (USGS) (2011) Landsat processing details. US Geological Survey, Reston, VA http://landsat.usgs.gov/ Landsat_Processing_Details.php

Wang J, Zhang X, Zhao Y, Shen Z, Shi P and Yu C (2008) Spatiotemporal pattern of climate changes in northern Tibet's Qiangtang plateau. Resour. Sci., 12, 1852-1859 [in Chinese with English summary]

Wang L, Xie Z, Wang X, Liu S, Ding L and Shangguan D (2011) The glacier area changes in the Qangtang Plateau based on the multi-temporal grid method and its sensitivity to climate change. J. Mt. Sci., 8(6), 882-893 (doi: 10.1007/s11629-011-1123-x)

Wang S and 6 others (2011) Response of glacier area variation to climate change in Chinese Tianshan mountains in the past 50 years. Acta Geogr. Sin., 66(1), 38-46 [in Chinese with English summary]

Wang X, Zhou A, Siegert F, Zhang Z and Chen K (2012) Glacier temporal-spatial change characteristics in Western Nyainqentanglha range, Tibetan plateau 1977-2010. Earth Sci. - J. China Univ. Geosci., 37(5), 1082-1092 [in Chinese with English summary]
Wang Z (1992) Glacier dimension in China and its analysis method. J. Arid Land Resour. Environ., 6(4), 1-10 [in Chinese]

Wu S, Yin Y, Zheng D and Yang Q (2007) Climatic trends over the Tibetan Plateau during 1971-2000. J. Geogr. Sci., 17(2), 141-151 (doi: 10.1007/s11442-007-0141-7)

Xiao C and 10 others (2007) Observed changes of cryosphere in China over the second half of the 20th century: an overview. Ann. Glaciol., 46, 382-390 (doi: 10.3189/172756407782871396)

Yang H and An R, eds (1988) Glacier inventory of China VII. Qinghai-Xizang Plateau interior area (drainage basins of Ayakkum Lake and Hoh Xil Lake). Science Press. Academia Sinica, Lanzhou Institute of Glaciology and Geocryology, Beijing [in Chinese]

Yao T, Jiao K, Tian L, Yang Z and Shi W (1995) Climatic variations since the Little Ice Age recorded in the Guliya ice core. Sci. China D, 39(6), 557-596 [in Chinese]

Yao T, Pu J, Lu A, Wang Y and Yu W (2007) Recent glacial retreat and its impact on hydrological processes on the Tibetan Plateau, China, and surrounding regions. Arct. Antarct. Alp. Res., 39(4), 642-650 (doi: 10.1657/1523-0430(07-510))

Yao T and 14 others (2012) Different glacier status with atmospheric circulations in Tibetan Plateau and surroundings. Nature Climate Change, 2(7), 663-667 (doi: 10.1038/nclimate1580)

Ye B, Ding Y, Liu F and Liu C (2003) Responses of various-sized alpine glaciers and runoff to climatic change. J. Glaciol., 49(164), 1-8 (doi: 10.3189/172756503781830999)

Zhang G, Xie H, Kang S, Yi D and Ackley SF (2011) Monitoring lake level changes on the Tibetan Plateau using ICESat altimetry data (2003-2009). Remote Sens. Environ., 115(7), 1733-1742 (doi: 10.1016/j.rse.2011.03.005)

Zhang Z and Jiao K eds (1988) Glacier inventory of China VII. Qinghai-Xizang Plateau interior area (drainage basins of Banggong Lake). Science Press. Academia Sinica, Lanzhou Institute of Glaciology and Geocryology, Beijing [in Chinese]

Zhao L, Ping C, Yang D, Cheng G, Ying D and Liu S (2004) Changes of climate and seasonally frozen ground over the past 30 years in Qinghai-Xizang (Tibetan) Plateau, China. Global Planet. Change, 43, 19-31 